\title{
Development of Democracy \& Phenomenon of Single Candidate in Regional Election (Pilkada)
}

\author{
Sarno Wuragil ${ }^{*}$ and Widayati**) \\ *) Master of Law, Faculty of Law, Universitas Islam Sultan Agung Semarang, E-mail: \\ sarno.wuragil@gmail.com \\ *) Faculty of Law, Universitas Islam Sultan Agung Semarang
}

\begin{abstract}
.
This study aims to answer the problem. What are the factors that cause the emergence of a single candidate in the 2020 Regent and Deputy Regent Election in Wonosobo, what are the obstacles in the regeneration of political parties in Wonosobo Regency? And What is the relationship between a single candidate for regional head elections with the development of Indonesian democracy? This research method uses a juridical-empirical approach. Based on the research, it can be concluded that the Election of Regent and Deputy Regent in Wonosobo Regency is only able to carry one candidate pair. Juridical factors underlie the existence of a single candidate pair. This is due to the constraints on regeneration by political parties which are said to be sudden and the traditional system of selecting candidates. This effect has a significant impact on the quality of democracy in Wonosobo Regency.

Keywords: Sovereignty; Democracy; Single Candidates; Pilkada.
\end{abstract}

\section{Introduction}

Regional head elections (Pilkada) are a form of the application of democracy in Indonesia. Theoretically, democracy is a government of the people, by the people and for the people. If it is related to the practice of state administration, even though a country claims to be a democratic country, in many ways that country actually ignores many democratic principles and principles. ${ }^{1}$

Democracy can not only be used as a decoration and a mere rhetorical discussion, democracy is also not only about the institutionalization of noble ideas about the ideal state life, but is a matter of tradition and egalitarian political culture in the reality of diversity and respect for differences. ${ }^{2}$

Thus, democracy explicitly requires recognition and respect for people's rights through various events such as through regional head elections which are held simultaneously. The choice to hold direct regional head elections cannot be separated from the norms contained in Article 18 paragraph (4) of the 1945 Constitution of the Republic of Indonesia which requires democratic elections.

However, democracy becomes blurred when there is a single candidate in the regional election. In the context of a single candidate in the Pilkada event, political parties supporting one candidate are often not based on ideological similarities but based more on political and economic interests. Whereas in holding regional head elections, the biggest role falls on political

\footnotetext{
${ }^{1}$ Nomensen Sinamo. (2014). Hukum Tata Negara Indonesia. Jakarta: Cetakan Ketiga. Permata Aksara. p. 181.

${ }^{2}$ Jimly Asshiddiqie. (2010). Konstitusi dan Konstitusionalisme Indonesia. Jakarta: Sinar Grafika. p. 58.
} 
parties. In fact, political parties should ideally prioritize the real goals of political parties, namely ideology-based coalitions (read: policy-seeking). ${ }^{3}$ Because in terms of political ideals, power is a tool to achieve the ideological goals of political parties.

One of the areas that held the Regent and Deputy Regent Election on December 9, 2020, is Wonosobo Regency, Central Java Province. The implementation of the Election for the Regent and Deputy Regent in Wonosobo Regency is only able to carry one candidate pair, according to the Wonosobo Regency KPU Decree Number: 408/PL.02.3-Kpt/3307/KPU-Kab/IX/2020, concerning the Determination of the Election of the Wonosobo Regent and Deputy Regent Year 2020 with One Candidate Pair. In this decision, the KPU of Wonosobo Regency appointed Afif Nurhidayat and M Albar as a Candidate Pair for Regent and Deputy Regent of Wonosobo Regency in 2020. The Afif-Albar pair are promoted by a coalition of Indonesian Democratic Party (PDI) Perjuangan, National Awakening Party (PKB), Party Golkar, Nasdem Party, Democratic Party, National Mandate Party (PAN) and Hanura Party.

The unique thing is that the single candidate pair in Wonosobo does not come from the incumbent element, either the incumbent regent or the vice regent incumbent. So that the polemic emerged into the public spotlight and the mass media. Many supported voting even though there was only one pair of candidates, but not a few also refused to postpone the implementation on the grounds that the election with one pair of candidates was deemed undemocratic.

Whereas the quality of the Pilkada can also be determined by the product of the Pilkada itself, namely being able to produce good and quality leaders. Another problem is that the election does not guarantee the elected political-government leadership is oriented towards the needs and interests of the wider community. Pilkada should be positioned as a medium to get regional heads who are more accountable and responsive in delivering better public services and shared welfare for citizens in the regions. This requires the commitment of political parties to promote candidates with capabilities as a consideration in recruiting candidates, not on their financial capabilities as the current trend. From the description. Therefore the authors are interested in researching more deeply about the single candidate in the 2020 Wonosobo Regent and Deputy Regent Election.

From the background above, a problem can be formulated, namely: What are the factors that caused the emergence of a single candidate in the Election of Regent and Deputy Regent in Wonosobo in 2020? What are the obstacles in the regeneration of political parties in Wonosobo Regency? And to regional heads with the development of Indonesian democracy?

\section{Research methods}

This research method uses a descriptive analysis method with a juridicalempirical approach and is presented in a narrative text. This type of research is in

\footnotetext{
${ }^{3}$ R. Widya Setiabudi Sumadinat, Dinamika Koalisi Partai-Partai Politik Di Indonesia Menjelang Dan Setelah Pemilihan Presiden Tahun 2014, Departemen Hubungan Internasional, Universitas Padjadjaran, Jurnal Wacana Politik Vol. 1, No. 2, Oktober 2016. p. 183-188.
} 
the form of field research. The research location is in the General Election Commission (KPU) of Wonosobo Regency, the General Election Supervisory Board for Wonosobo Regency, and the United Development Party (PPP) in Wonosobo Regency. While the research data uses primary data in the form of interviews, observation and documentation and secondary data in the form of literature studies.

\section{Results and Discussion}

\subsection{Factors that Cause the Appearance of Single Candidates in the Election of Regent and Deputy Regent in Wonosobo in 2020}

Since 2005, news about the Regional Head Election (Pilkada) in Indonesia has always been a very broad public concern. The various cases and problems during the Pilkada process that occurred gave the impression that it was as if the position of the Regional Head was not only something that was really worth fighting over, but also an easy task or job, so that almost everyone could do it. As a result, many parties are competing for the position and seem to ignore the risks or obligations that must be assumed in leading the administration of this Regional Government which is actually very heavy. 4

The role of the regional head is very large in the implementation of regional tasks, especially autonomous tasks. In this regard, the success or failure of regional tasks depends very much on the regional head as the manager of the region concerned. ${ }^{5}$

While the 2020 Pilkada in Wonosobo can be said to attract the attention of the public. Due to a single candidate. The emergence of a single candidate in Wonosobo certainly made the political dynamics heated up, especially since this is the first time there has been a single candidate. The most dominant factor in the emergence of a single candidate is the juridical factor.

There isThe two juridical bases of the single candidate are the Constitutional Court Decision Number 100/PUU-XIII/2015 which states that regions that only have one pair of regional head candidates can participate in the General Election simultaneously. With this MK decision the KPU issued General Election Commission Regulation Number 13 of 2018 concerning Amendments to the General Election Commission Regulation Number 14 of 2015 concerning the Election of Governors and Deputy Governors, Regents and Deputy Regents, and/or Mayors and Deputy Mayors with One Candidate Pair. So that the ballot papers in the election contain two columns consisting of one column containing photos and names of the pairs of candidates and a blank column with no pictures.

Second, the determination of a single candidate is based on the Decree of the General Election Commission of Wonosobo Regency Number 408/PL.02.3Kpt/3307/KPU-Kab/IX/2020 concerning the Determination of the Election of the Wonosobo Regent and Deputy Regent of 2020 with one Candidate Pair. In this

\footnotetext{
${ }^{4}$ Abdul Gafar Karim. (2003). Kompleksitas Persoalan Otonomi Daerah di Indonesia, Jakarta: Pustaka Pelajar. p. 173.

${ }^{5}$ Manullang. (1983). Beberapa Aspek Administrasi Pemerintah Daerah. Jakarta: Pembangunan. p. 31.
} 
decision, the KPU of Wonosobo Regency appointed a pair of Afif Nurhidayat and M Albar as a Candidate Pair for Regent and Candidate for Deputy Regent of Wonosobo Regency in $2020 .^{6}$

The Regional General Election Commission (KPUD) as the implementer of the Regional Head Election is certainly not the sole actor who will determine the success of the direct Pilkada implementation. Political parties as well as candidates for Regional Heads as the main players in the Regional Head Election, of course, also have a considerable contribution to the running of Pilkada in a safe and democratic manner. ${ }^{7}$

Facts in the field obtained when he had the opportunity to interview Amirudin ${ }^{8}$ the emergence of a single candidate is due to:

"First, the majority of parties build a coalition to only propose one pair of candidates. The coalition consists of PDI-P (11 seats), PKB (10), Golkar (4), Democrat (3), Nasedem (3), PAN (2) and Hanura (2)". Second, the remaining seats that still meet the candidate's requirements, namely Gerinda (6 seats), PPP (3 seats) and Perindro (1 seat), until the end of the registration extension period, apparently they have not found an agreement on the candidate to be carried. Until the end of the registration extension period, only PPPs have registered with the KPU. Because they do not meet the requirements, the KPU does not accept the registration.

Look The results of the interview above do not be surprised if the KPU held a plenary session and produced a decision as stated in the Minutes of the Plenary Meeting of the General Election Commission of Wonosobo Regency Number 285/PL.02.3-BA/3307/KPU-Kab/IX/2020 on September 23, 2020 set Determination of Candidate Pairs for Regent and Deputy Regent who meet the Requirements to Become the Election of the Regent and Deputy Regent of Wonosobo in 2020 through the Decree of the General Election Commission of Wonosobo Regency Number: 408/PL.02.3-Kpt/3307/KPU-Kab/IX/2020 concerning Determination of the Election of Regent and Deputy Regent of Wonosobo in 2020 with One Candidate Pair.

While Bawaslu responded to the single candidate in Wonosobo Regency stating that: "In Wonosobo Regency in the 2020 Pilkada, the number of applicants for candidate pairs is only one pair, namely Afif Nurhidayat and Muhammad Albar. This candidate is supported by a coalition of parties: PDI-P, National Awakening Party (PKB), Golkar Party, Nasdem Party, Democrat Party, National Mandate Party (PAN) and Hanura Party. The total is 35 seats, or 77 percent of the total 45 seats in the Wonosobo DPRD. Of these, there are still 10 seats, or 23 percent. Consists of the Gerindra Party: 6 seats, the United Development Party (PPP): 3 seats and the Perindo

\footnotetext{
6 Wonosobo Regency KPU Decree Number: 408/PL.02.3-Kpt/3307/KPU-Kab/IX/2020 concerning Determination of the Election of the Wonosobo Regent and Deputy Regent of 2020 with One Candidate Pair.

7 Agus Hadiawan, Evaluasi Pemilihan Kepala Daerah Langsung Di Propinsi Lampung, Ilmu Pemerintahan FISIP Universitas Lampung, Bandar Lampung, Jurnal Ilmiah Administrasi Publik dan Pembangunan, Vol.3, No.7, Juli-Desember 2009.

${ }^{8}$ Amirudin, Div Sosialisasi Pendidikan Pemilih Partisipasi Masyarakat dan SDM, Hasil Wawancara bertempat di Sekretariat KPU Jl. Sabuk Alu No.2 B, Wonosobo Timur, Kec. Wonosobo, Kabupaten Wonosobo, Jawa Tengah 56311, Rabu, 27/1/2021.
} 
Party: 1 seat. Of these 3 parties, Gerindra and Perindo did not register candidates. Meanwhile PPP is registering candidates, namely the pair of Eko Purnomo - Jefri Asmara". ${ }^{\circ}$

From the results of the interview above, it can be concluded that one of the factors that led to the occurrence of a single candidate in Wonosobo was weighsrequirements to become a candidate for regional head. The legislative regulations regarding the elections state that the requirements to become a regional head candidate from the political party path must consist of $20 \%$ of the number of political party seats in the DPRD or $25 \%$ of the votes acquired by political parties. If it does not meet these requirements when verified by the Regency KPU, the minimum requirement for nomination is not fulfilled, which will result in rejection. The phenomenon of a single candidate in Wonosobo Regency has created a new round of supervision by Bawaslu. ${ }^{10}$

\subsection{Constraints in the Cadre of Political Parties in Wonosobo Regency}

Miriam Budiardjo stated that "a political party is an organized group whose members share the same orientation, values and ideals. The aim of this group is to gain political power and gain political position constitutionally in order to carry out its programs ".11

Based on the definition of political parties above, in this paper the author uses the definition of political parties as contained in Article 1 number 1 of Act No. 2 of 2011 concerning Amendments to Act No. 2 of 2008 concerning Political Parties. Act No. 2 of 2011, which includes the requirements for the formation of political parties in Indonesia, the objectives and functions of political parties, the rights and obligations of political parties, and various other regulations related to the party system in Indonesia. With the existence of the party law, of course it is more procedurally affirmed about all matters related to how political parties themselves should be.

Basically, the pattern of regeneration includes all party activities, starting from admitting members, fostering the quality of cadres, to assigning party cadres to strategic positions. Cadre formation for political parties is an important effort, because each party must prepare and nurture cadres to become party members with optimal leadership and organizational skills. Cadreization is carried out in a system that is interconnected with one another, including planning, implementing, and evaluating regeneration.

\footnotetext{
${ }^{9}$ Sumali Ibnu Chamid, Chairperson of the Bawaslu of Wonosobo Regency, interview at the Bawaslu office at Jl. Major General Bambang Sugeng Km. 03 Mandala Terminal Complex, Perum Purnamandala, Bumireso, Kec. Wonosobo, Kab. Wonosobo, Thursday, January 28, 2021.

10 Bawaslu has the duty, authority and obligation to supervise the stages of candidacy for the Election of Regent and Deputy Regent as stipulated in the mandate of Act No. 7 of 2017 concerning General Elections. The supervisory model refers to Law of the Republic of Indonesia Number 10 of 2016 concerning the Second Amendment to Act No. 1 of 2015 concerning Stipulation of Government Regulations in Lieu of Act No. 1 of 2014 concerning Election of Governors, Regents and Mayors into Law.

11 Miriam Budiardjo. (1986). Aneka Pemikiran tentang Kuasa dan Wibawa. Jakarta: Sinar Harapan. p. 403-404.
} 
The electability of political parties greatly affects society. Many of the terms used in general elections are still difficult for ordinary people to digest. Is it just for popularity with frequent appearances, or to increase the electability. In society, it is often interpreted that people who have popularity are considered to have high electability.

So that the Wonosobo Regency United Development Party (PPP) in maintaining its electability uses two types of political recruitment, namely, first, an efficient model, a recruitment process that is carried out openly and flexibly. In this model, party leaders can recruit people from various groups or circles. This model is not based on an institutionalized political career. Second, the internal party democracy model. This model is more institutionalized, according to a clear career path, the rank of promotion in the party structure is also more visible. Thus the model can be explained that candidate selection is related to the preparation of candidate names on the ballot paper, while political recruitment is interpreted as the process of looking for potential candidates to be nominated.

According to Udik Ridawan as chairman of the United Development Party, in the results of his interview said that 12 :

"(1) The regeneration of the United Development Party in Wonosobo in the recruitment and regeneration process has tended to apply traditional patterns and styles. The party that was developed was characterized by a catch all party which did not yet have a clear and specific social base, and still depended on individual figures. Political parties also face challenges in the regeneration process. Most of the political parties do not yet have a clear regeneration system, nor do political recruitment sources tend to be oligarchic".

"(2) The recruitment pattern still follows the line determined by primordial factors such as religion, regional relations, regional equality, as well as factors of loyalty and closeness to top party leaders. The domination of party leaders in the selection and candidacy process for legislative member candidates. The image of politicians hopping the fence, rich people, and businessmen whose political abilities are often doubted is one of the phenomena of the many problematic slices in the political recruitment and candidacy process carried out by political parties ".

"(3) In fulfilling recruitment needs, the challenges faced by the United Development Party are not light. In terms of the time it is sometimes "tight", the United Development Party is also required to provide good political candidates who meet public expectations. The public also expects parties to be present in every activity that has a positive impact on the wider community or not. The challenge is whether political parties can carry out their roles and functions that can be felt by the public at large. Don't let the public think that parties are only present before and during the general election".

"(4) Thus, the regeneration of political parties in Wonosobo Regency runs as it should, even though PPP admits this is tricky. PPP is always committed to forming cadres with integrity and capability".

12 Udik Ridawan, Ketua Partai Persatuan Pembangunan (PPP), wawancara bertempat di Kantor Partai Persatuan Pembangunan beralamat di Jl. Tosari No. 195, Tosari, Wonosobo Tim, Kec/Kab. Wonosobo, Jum`at, 29 Januari 2021. 
Thus the various problems in recruitment faced by the United Development Party cannot be separated from the history of the party's establishment. Social cleavage is one of the factors that causes it. Parties that are born from the process of social division generally cannot escape from the constituent elements in the recruitment and regeneration process. The United Development Party's political elite selection recognizes three forms of selection, namely first, the institutional model, the easiest form to explain the form of elite selection, namely through engineering regulations such as the presidential threshold. The second is the cultural model, in which this model is the most characteristic form of elite selection. The cultural model has meaning in the patron-client relationship within the party so that this relationship becomes a source of legitimacy for political regeneration within the party, both in the chairmanship and in the candidacy process. The third is the transaction selection model (transactional selection) that occurs in many parties with high factionalization potential. The occurrence of a form of transactional selection will appear when there are factions competing within the party's internal. Transactions can be in the form of political or financial support.

\subsection{The Linkage of Single Candidates for Regional Head Election with the Development of Indonesian Democracy}

Sovereignty is the concept of supreme authority in a country.13Popular sovereignty is meant by people's power as a match or counter to the power of a single ruler in power. In this case a sharp dividing line is drawn between the people who are ruled on the one hand and the rulers of society as the government on the other. What is truly sovereign in this relationship is the people who are ruled. ${ }^{14}$

The sovereignty of the people believes that in fact the sovereign in a country is the people, not the rulers. Therefore, in the understanding of people's sovereignty, a very well-known slogan appears, namely "vox populi suprema lex" which means that the voice of the people is the highest law. It is the people who are sovereign and represent or hand over their power to the state. ${ }^{15}$ So that the will of the people is the only source of power for every government. ${ }^{16}$

With such understanding, the people will give birth to a rule that is beneficial and protects their rights. In order for this to happen, a joint regulation is needed that supports and becomes the basis for the life of the state to guarantee and protect the rights of the people. This is where the concept of democracy was born.

One form of democracy is none other than Pilkada. The Wonosobo Regency democracy party on December 9, 2020 with a single candidate pair became a sharp

\footnotetext{
13 Jimly Asshidiqie. (1994).Gagasan Kedaulatan Rakyat dalam Konstitusi dan Pelaksanaannya di Indonesia. Jakarta: Ichtiar Baru van Hoeve. p. 11.

${ }^{14}$ Arief Budiman. (2002). Teori Negara, Negara, Kekuasaan dan Ideologi. Jakarta: PT Gramedia Pustaka Utama. p. 25-26.

${ }^{15}$ M. Iwan Satriawan dan Siti Khoiriah. (2016). Ilmu Negara. Jakarta: cetakan pertama. Rajawali Pers. p. 59

16 Ibid. Jimly Asshiddiqie. Gagasan .... p. 11.
} 
spotlight towards the two institutions, namely the KPU and Bawaslu. This is because the public doesn't seem to believe in an election with one candidate pair. Responses were also given by the KPU and Bawaslu regarding this issue. The KPU's response is: "The KPU as the election organizer implements the existing regulations, that when there is only one pair of candidates, the public is given the choice to choose a candidate pair or not a candidate pair. So in the ballot papers the picture of the candidate pair is side by side with an empty column. The existence of this empty column is a democratic way to accommodate the rights of voters. For voters who do not like candidate pairs, they are given the opportunity to continue to voice their rights by having an empty column. However, many parties stated that the existence of an empty column was not sufficient to guarantee the people's voting rights. The blank column is considered not fully an equal choice for the people's suffrage". 17

Meanwhile, Bawaslu's responses are: "The emergence of a single candidate normatively does not violate the rules. Because indeed Act No.10 of 2016 provides this space and is confirmed by the Decree of the Constitutional Court Number 100/PUU/XIll/2015. Where when in the candidate candidate registration stage until it is extended once ( 3 days) the applicant remains only one candidate pair, then the stage continues. The mechanism in the ballot consists of a picture of a candidate pair and a blank column as a valid choice".18

From the above statement, it has actually raised concerns that regional head elections with a single candidate will reduce the quality of democracy. If a single candidate is justified in the regional head election, there could be that one day legal smuggling will occur. It is feared that this will lead to liberalization by capital owners to 'buy' political parties to only nominate 1 (one) pair.

Whereas regional head elections as a manifestation of the implementation of people's sovereignty are held as Article 18 paragraph (4) of the 1945 Constitution of the Republic of Indonesia also mandates that regional heads must be elected democratically. What happened in the simultaneous regional elections in 2020 with the phenomenon of the emergence of a single candidate, especially what happened in Wonosobo District, if viewed in theory, is not something that can be said to be undemocratic. Participation is also the main point in the implementation of political democracy. Even though there is only one pair of candidates in the Pilkada, the voting process must still be carried out because the people's right to vote is the people's sovereignty whose existence is guaranteed by the constitution.

According to researchers, interpreting democracy cannot be interpreted in pieces. Democracy that is carried out by a country cannot be equated with democracy that is practiced by other countries. It is the history and background of the birth of democracy in a country that determines the concept of democracy.

\footnotetext{
${ }^{17}$ Amirudin, Div of Voter Education for Community Participation and Human Resources, Interview Results at the KPU Secretariat Jl. Belt Alu No.2 B, Wonosobo Timur, Kec. Wonosobo, Wonosobo Regency, Central Java 56311, Wednesday, 27/1/2021.

${ }^{18}$ Sumali Ibnu Chamid, Chairperson of the Bawaslu of Wonosobo Regency, interview at the Bawaslu office at Jl. Major General Bambang Sugeng Km. 03 Mandala Terminal Complex, Perum Purnamandala, Bumireso, Kec. Wonosobo, Kab. Wonosobo, Thursday, January 28, 2021.
} 
Primarily, democracy is expected to avoid tyrannical power by focusing on humans or anthropocentricity. The concept of democracy and democratization will always develop in accordance with human consciousness and the needs of the state. The concept of democracy adopted in Indonesia calls for equal rights and freedom to choose and exercise their voting rights in democratic contests as well as for regional head candidates, the right to be elected is a right that must be respected.

\section{Closing}

Based on the explanation above, it can be concluded: first, the factors that caused the emergence of a single candidate in the election of the Regent and Deputy Regent in Wonosobo in 2020 were juridical factors. Second, the obstacles in the regeneration of political parties in Wonosobo Regency are (1), the recruitment and regeneration processes have tended to apply traditional patterns and styles. (2), the recruitment pattern still follows the line determined by primordial factors. Third, the linkage of a single candidate for regional head elections with the development of Indonesian democracy is what happened in the simultaneous regional elections in 2020 with the phenomenon of the emergence of a single candidate, especially in Wonosobo Regency, if viewed theoretically is not something that can be said to be undemocratic. Thus the author's suggestions include (1) Political parties must manifest democratic politics in political processes. (2) Bawaslu needs to initiate stakeholder consolidation, especially from civil society election observers. (3) The KPU needs to be more intensive in conducting voter education, especially for beginner voters, as well as for other stakeholders related to election implementation techniques.

\section{References}

\section{Journals:}

[1] Agus Hadiawan, Evaluasi Pemilihan Kepala Daerah Langsung Di Propinsi Lampung, Ilmu Pemerintahan FISIP Universitas Lampung, Bandar Lampung, Jurnal Ilmiah Administrasi Publik dan Pembangunan, Vol.3, No.7, JuliDesember 2009.

[2] R. Widya Setiabudi Sumadinat, Dinamika Koalisi Partai-Partai Politik Di Indonesia Menjelang Dan Setelah Pemilihan Presiden Tahun 2014, Departemen Hubungan Internasional, Universitas Padjadjaran, Jurnal Wacana Politik Vol. 1, No. 2, Oktober 2016.

\section{Books:}

[1] Abdul Gafar Karim. (2003). Kompleksitas Persoalan Otonomi Daerah di Indonesia, Jakarta: Pustaka Pelajar

[2] Arief Budiman. (2002). Teori Negara, Negara, Kekuasaan dan Ideologi. Jakarta: PT Gramedia Pustaka Utama.

[3] Jimly Asshiddiqie. (2010). Konstitusi dan Konstitusionalisme Indonesia. Jakarta: Sinar Grafika.

[4] Jimly Asshidiqie. (1994).Gagasan Kedaulatan Rakyat dalam Konstitusi dan Pelaksanaannya di Indonesia. Jakarta: Ichtiar Baru van Hoeve. 
[5] M. Iwan Satriawan dan Siti Khoiriah. (2016). Ilmu Negara. Jakarta: cetakan pertama. Rajawali Pers.

[6] Manullang. (1983). Beberapa Aspek Administrasi Pemerintah Daerah. Jakarta: Pembangunan

[7] Miriam Budiardjo. (1986). Aneka Pemikiran tentang Kuasa dan Wibawa. Jakarta: Sinar Harapan.

[8] Nomensen Sinamo. (2014). Hukum Tata Negara Indonesia. Jakarta: Cetakan Ketiga. Permata Aksara.

\section{Regulation:}

[1] Act No. 7 of 2017 concerning General Elections.

[2] Bawaslu has the duty, authority and obligation to supervise the stages of candidacy for the Election of Regent and Deputy Regent as stipulated in the mandate of Act No. 7 of 2017 concerning General Elections. The supervisory model refers to Law of the Republic of Indonesia Number 10 of 2016 concerning the Second Amendment to Act No. 1 of 2015 concerning Stipulation of Government Regulations in Lieu of Act No. 1 of 2014 concerning Election of Governors, Regents and Mayors into Law.

[3] Law of the Republic of Indonesia Number 10 of 2016 concerning Second Amendment to Act No. 1 of 2015 concerning Stipulation of Government Regulations in Lieu of Act No. 1 of 2014 concerning Election of Governors, Regents and Mayors into Law.

[4] Wonosobo Regency KPU Decree Number: 408/PL.02.3-Kpt/3307/KPU$\mathrm{Kab} / \mathrm{IX} / 2020$ concerning Determination of the Election of the Wonosobo Regent and Deputy Regent of 2020 with One Candidate Pair. 